University at Buffalo School of Law

Digital Commons @ University at Buffalo School of Law

Journal Articles

Faculty Scholarship

10-1-2019

\title{
The Law and Economics of Redistribution
}

Matthew Dimick

University at Buffalo School of Law

Follow this and additional works at: https://digitalcommons.law.buffalo.edu/journal_articles

Part of the Economics Commons, Inequality and Stratification Commons, and the Law Commons

\section{Recommended Citation}

Matthew Dimick, The Law and Economics of Redistribution, 15 Ann. Rev. L. \& Soc. Sci. 559 (2019).

Available at: https://digitalcommons.law.buffalo.edu/journal_articles/958

Posted with permission from the Annual Review of Law and Social Science, Volume 15 @ by Annual Reviews, http://www.annualreviews.org.

\section{C. ${ }_{\text {COPYRIGHT }}^{\text {N }}$}

This Article is brought to you for free and open access by the Faculty Scholarship at Digital Commons @ University at Buffalo School of Law. It has been accepted for inclusion in Journal Articles by an authorized administrator of Digital Commons @ University at Buffalo School of Law. For more information, please contact lawscholar@buffalo.edu. 


\title{
The Law and Economics of Redistribution
}

\author{
Matthew Dimick*
}

November 21, 2017

\begin{abstract}
Should legal rules be used to redistribute income? Or should income taxation be the exclusive means for reducing income inequality? This article reviews the legal scholarship on this question. First, it traces how the most widely-cited argument in favor of using taxes exclusively - Kaplow \& Shavell's (1994) "double-distortion" argumentevolved from previous debates about whether legal rules could even be redistributive and whether law and economics should be concerned exclusively with efficiency or with distribution as well. Next, it surveys the responses to the double-distortion argument. These responses appear to have had only limited success in challenging the sturdy reputation of the double-distortion argument. Finally, it concludes by highlighting new directions in a debate revived by increasing economic inequality.
\end{abstract}

Keywords: Inequality, Redistribution, Legal Rules, Taxation, Efficiency, Equity, Social Welfare

*Direct correspondence to Matthew Dimick, University at Buffalo School of Law, 618 John Lord O'Brian Hall, Buffalo NY 14260-1100. E-mail: mdimick@buffalo.edu. 


\section{Introduction}

Should legal rules be used to address income inequality? Or should the income tax system be the exclusive means to redistribute income? This question has existed in some form for a very long time. Within legal scholarship it has been around at least since the rise of the law-and-economics movement in the 1970s and 80s. The dust had largely settled by the publication of Kaplow and Shavell's (1994) "Why the Legal System Is Less Efficient than the Income Tax in Redistributing Income," though the debate has never completely disappeared. Now, with income inequality on the rise, and a cause of public concern, the debate shows every sign of returning.

The purpose of this article is to review the debate on the law and economics of redistribution. It does so in three parts. Section 3 traces the debate's origins in legal scholarship up to its culmination in the seminal - and, for many, debate-concluding - article by Kaplow and Shavell (1994). Kaplow and Shavell crafted a clear and elegant argument - dubbed the "double-distortion" argument-demonstrating why the income tax should be the exclusive means to redistribute income. Section 4 surveys the responses to Kaplow and Shavell's double-distortion argument. These responses appear to have had only limited success in challenging the sturdy reputation of the double-distortion argument. Finally, Section 5 concludes by highlighting some unanswered questions and pointing to some new directions in the revived debate. I believe the double-distortion argument is open to challenge - although this still remains to be decisively demonstrated.

The argument that legal rules should not be used for distributive objectives is primarily associated with law-and-economics scholarship. But at least three reasons foreclose any attempt to dismiss this position based on this association alone. First, the argument is also deeply ingrained within political liberal thought. The position is quite explicitly found in the work of John Rawls (1999, 254), as well as many other political liberals (e.g., Alstott, 1999). The position cannot therefore simply be dismissed as a "pro-market" conservative argument. Law-and-economics scholars may have devised the most sophisticated argument for using taxes exclusively to redistribute income, but it is not a debate between liberals and conservatives.

Second, it is also easy to misinterpret the debate as one between law-and-economics and other intellectual disciplines. Yet, as this review will show, this is an erroneous characterization. The debate is better understood as one taking place within law and economics. Some of the better arguments in favor of considering equity in legal rules come from those trained in economics or who are self-identified members, and even founders, of the economic analysis of law. Even contributors to the debate who do not identify as law-and-economics scholars use the same economic tools, methods, and theories as deployed by the opposing side (Kelman, 1987, 151).

Third, it is likewise tempting to dismiss the double-distortion argument because of its embrace of utilitarianism. Moral critiques of efficiency and utilitarianism abound. And so it is easy to dismiss an argument that tells us to uses taxes rather than legal rules merely because it is more efficient to do so. Yet this objection, in my view, also fails. Many, if not most, people who would consider the effects of legal rules on rights, justice, or fairness would also consider their effects on individuals' wealth or well-being. That is, a big part of why we care about inequality and poverty is because of their consequences for well-being. So if an 
argument says that using taxes exclusively will improve the well-being of the poor, it is one we should pay attention to, regardless of the abstract normative justification.

\section{The Economics Background to the Debate in Legal Scholarship}

Before discussing the redistribution debate in legal scholarship, I will provide some background to the debate that begins outside legal scholarship, within economics.

The idea that income taxes should be the exclusive means of redistributing economic resources is deeply entrenched within academic economic thought. One of the bedrock propositions in welfare economics is the so-called Second Fundamental Theorem of Welfare Economics 11 The First Fundamental Theorem states that a perfectly competitive economy (so defined) will be Pareto efficient. That is, in a perfectly competitive economy, no one can be made better off without making someone worse off. There may be many - possibly infinite-Pareto efficient allocations associated with different distributions of income. This is where the Second Fundamental theorem comes in. The Second Fundamental theorem says that any Pareto efficient allocation of resources -including those with more "desirable" distributions of income - can be achieved with lump sum transfers. ${ }^{2}$

Thus, a government need not interfere with prices or markets to achieve a (distributionally) desirable outcome. This is quite an attractive scenario. It requires only two policy instruments: promote competition and lump-sum taxes. As Hindriks and Myles (2013) write, "If this approach could be applied in practice, then economic policy analysis would reduce to the formulation of a set of rules that guarantee competition and the calculation and redistribution of the lump-sum taxes. The subject matter of public economics, and economic policy, in general, would then be closed" (p. 424). It is this policy simplicity that also undoubtedly underlies the attractiveness of tax-only position against the use of legal rules to redistribute income. The case for that position, however, requires addressing separate challenges, as we will soon see.

The problem is that using lump sum taxes and transfers for redistributive objectives is impossible in practice. Differentiated lump sum taxation, as in perfect competition generally, requires perfect and complete information. In order for a tax to be lump sum, the person on whom the tax is levied must not be able to change the amount of tax she pays by changing her behavior (Hindriks and Myles, 2013, 428). Otherwise, the tax will "distort" her incentives, and lead us away from a Pareto efficient allocation. By this definition, most tax instruments are emphatically not lump sum. Income taxes, commodity taxes, estate taxes - the amount a person pays for any of these can be changed by altering behavior. Poll taxes - a uniform amount levied on each person - come close to being lump sum, but even in this case experience suggests that taxes can be avoided through behavior $\mathrm{S}^{3}$ In any case, if

\footnotetext{
1 Fennell and McAdams (2016, 1065 n. 42) and McCaffery (2005, 817 n. 21) also recognize the link between the taxes-versus-legal-rules debate and the Fundamental Theorems of Welfare Economics.

${ }^{2}$ I use scare quotes because the standard of Pareto efficiency has no way of ordering Pareto efficient allocations, either in terms of distribution or by any other criterion. Making distributional judgments within economics requires additional, and more controversial, assumptions.

${ }^{3}$ The United Kingdom implemented a poll tax in the 1980s as a source for local revenue. As Hindriks and
} 
one wants to achieve a more equitable distribution through lump sum taxes, which include transfer payments, they will not be uniform across individuals. Endowment taxation seems to be the only way to achieve this objective, but endowment taxation requires knowing the abilities of individuals - their endowment - something which is private information to those individuals themselves. And individuals do not have the incentive to report information about their abilities honestly, if it will be used to their disadvantage. ${ }^{4}$ Thus, imperfect and incomplete information prevents the use of lump-sum taxation to achieve a more desirable distribution of resources.

\section{Taxation, Legal Rules, and Redistribution}

The debate about legal rules and redistribution thus starts outside of legal scholarship. This section explores the evolution of the debate within legal scholarship, from its origins to the development of the "double-distortion" argument. It is important to distinguish three separate claims in this debate: (1) should the economic analysis of legal rules consider only their consequences for efficiency, or for equity as well; (2) is it even possible for legal rules to redistribute; and (3), if possible, is taxation superior to legal rules as a tool for redistribution? If anything, the debate helped to clarify these distinct issues as it evolved.

\subsection{The Origins of the Debate in Legal Scholarship}

Within legal scholarship, the debate begins in the 1970s. The radix can arguably be designated as Bruce Ackerman's (1971) "Regulating Slum Housing Markets on Behalf of the Poor." Although he did not identify himself as a law-and-economics scholar, Ackerman's analysis is straightforwardly economic.

Ackerman demonstrated that under certain conditions housing code enforcement could redistribute from rich to poor. In the simplest, initial version of his model, he assumes, in addition to perfect competition $\sqrt{5}^{5}$ that housing supply is fixed. Specifically, the next, best available use of the landlord's property is low enough to ensure that, even with the costs of housing code enforcement, the landlord will not convert or abandon (or destroy) the building. ${ }^{6}$

To reach his critical result, Ackerman adopts one more condition. He assumes the existence of a small class of Slumville residents who are not willing to pay for improved housing. For instance, suppose two types of families live in Slumvilles's 100,000 residential units:

Myles (2013) explain, it failed because "taxpayers could avoid paying the tax by ensuring that their names did not appear on any official registers. Usually this was achieved by moving house and not making any official declaration of the new address. ... This 'disappearance' is a change in behavior that reduces the tax burden" (p. 428).

${ }^{4}$ Despite the impracticality of endowment taxation, it has been the subject of a rich debate in the legal literature about its normative justification, even as an "ideal" tax (see, e.g., Hasen, 2006, Stark, 2005. Zelenak, 2006). The debate has centered around the illiberalism or not of taxing highly people who have the potential to earn high incomes, but may prefer not to for, say, lifestyle reasons.

${ }^{5}$ Specifically, he assumes rational self-interest, no market power, perfect information, and housing of uniform quality. In the initial version, he also assumes perfect mobility within the area where all poor residents live ("Slumville") and no entry or exit outside this area.

${ }^{6}$ This does not necessarily mean that landlords are earning even relatively high profits (ibid., p. 1103). 
90,000 families who would be willing to pay for improvements and 10,000 families who would not.7 In a competitive housing market, these 10,000 families essentially determine the price for housing. And because they are not willing to pay for housing improvements, landlords are unable to pass on the costs of code-enforced improvements to tenants. Thus, the 90,000 poor Slumville tenants, who do value the improvements, are better off without any increase in rent. Landlords, who now face higher costs because of housing code enforcement, are worse off. The housing code is redistributive.

Ackerman's article provoked a small debate about the efficiency and distributive effects of housing regulation. Several critiques of Ackerman's article appeared (Komesar, 1973; Rabin, 1983 ) as did several articles defending or extending Ackerman's analysis (Markovits, 1976, Kennedy, 1987). Notably, not all of those who disagreed with Ackerman's analysis were opposed to his conclusions (Komesar, 1983, 613). Furthermore, all of the participants accepted the basic framework of economic theory, including those who identified with different schools of legal thought (e.g., Kennedy, 1987). Finally, one can see emerging within this debate the three distinct questions that were raised at the beginning of this section (i.e., 3.1).

\subsection{Should Economic Analysis of Law Consider Equity as well as Efficiency?}

As we saw in Section 2, the Pareto criterion is deeply embedded in economic thought. One normative justification for Pareto efficiency is that it rests on a principle of consent (Posner, 1979, 489-90). Since a Pareto improvement is one where at least one person is made better off and no one worse off, who can argue with that? In this sense, Pareto efficiency is neutral: distributive issues are irrelevant to the economic analysis of legal rules. Everyone benefits from a bigger pie.

Yet, as legal scholars above all were quick to point out, few legal rules have such innocent effects. Typically, changes in legal rules have winners and losers. Recognizing this, scholars advanced a new definition of efficiency: Kaldor-Hicks efficiency. ${ }^{8}$ Under the Kaldor-Hicks test, a legal rule change is efficient if the aggregate benefits exceed the aggregate costs. In other words, if the winners could monetarily compensate the losers, the change is efficient.

Although distribution remains an issue under the Kaldor-Hicks criterion, the fact that winners could compensate losers suggests that everyone could still be made better off. Posner (1979) developed an "ex-ante consent" theory to advance this view. For example, consider two legal rules: strict liability, which favors pedestrians, and negligence, which favors automobile drivers. For the sake of discussion, also assume that strict liability is inefficient and negligence is efficient. Now, it is clear which rule you'd prefer if you knew if you were a driver or a pedestrian. But, from behind a veil of ignorance, not knowing which you would be, your best bet is to choose the efficient rule - negligence-because this rule minimizes ex-ante, expected costs. And, indeed, since many of us are sometimes drivers and sometimes

\footnotetext{
${ }^{7}$ Not that these 10,000 families do not recognize that they would benefit from improved housing, as Ackerman notes, just that their poverty makes them unwilling to allocate any more of their scare funds to purchase it.

${ }^{8}$ For a remarkably clear and rigorous introduction and critique to the concepts of Pareto efficiency, Kaldor-Hicks efficiency, and wealth maximization, see Coleman (1979).
} 
pedestrians, we can say that winners and losers are (often? sometimes?) the same. Under this argument, Pareto efficiency's "consent" attribute survives under Kaldor-Hicks efficiency.

In response to the alleged neutrality of Kaldor-Hicks efficiency, critics showed that it could give arbitrary and indeterminate answers, especially when distributive issues - wealth effects - were included in the analysis (Kelman, 1987, 141-50). Suppose a factory has the right to pollute, with the consequence that the pollution lowers home values in the neighboring community. Since this influences the homeowners' wealth, it also contracts their budget constraints, which affects their demand for goods, including their willingness to "purchase" the factory's entitlement to pollute. Given their lower wealth, they may not be willing to pay the factory to stop polluting. Conversely, suppose we give the homeowners the property entitlement to enjoin the factory from polluting. Without pollution, home values are higher, wealth is higher, and the enjoyment of a pollution-free environment greater as well. In this case, the amount the factory might have to pay the homeowners for the right to pollute may be higher than what the homeowners were willing to pay to get the factory to stop polluting. If so, homeowners may prevent pollution in the case where they own the entitlement but permit it when the factory has the entitlement. In this scenario, either allocation of the entitlement is "efficient" and we cannot decide which one is superior on Kaldor-Hicks grounds.

The efficiency-only view could be attacked from other angles from within law and economics. Readers familiar with this literature will be aware of the so-called Coase Theorem. The Coase Theorem says that in a world of zero transaction costs, the allocation of resources - efficiency - is independent of initial legal entitlements. Less appreciated is what Schwab (1989, 1195) dubs the "Distributive Corollary" to the Coase Theorem: "With zero transaction costs, initial entitlements cannot be justified on efficiency grounds, and so should be awarded on the basis of need or desert." Stated slightly differently, the distributive corollary says that although legal entitlements do not affect efficiency they will affect the distribution of resources $9^{9}$ at least in bargaining environments or "thin" markets (where bargaining over surplus takes place) (ibid., p. 1178-79).10

On this interpretation, the Coase Theorem threatens to upend the entire efficiency edifice. With zero transaction costs, the choice of legal rules is irrelevant for efficiency; only distribution matters. This is, of course, the complete opposite of the argument that the economic analysis of law should consider efficiency only and ignore distribution. The rub, of course, is that we do not live in a world of zero transaction costs. With positive transaction costs, we cannot be sure about the consequences of legal rules for either efficiency or distribution.

Yet, even with positive transaction costs, Calabresi (1991) argued that distributional issues could not be ignored. Transaction costs, he argues, no less than existing technology, define what is maximally feasible in any society. "It follows that any given society is always

\footnotetext{
${ }^{9}$ The corollary has obvious similarities with both older and newer critiques of both the tax-only view of redistributive policy as well as law and economics more generally. In terms of the older, see Hale (1923. 1943). In terms of the newer, see Kennedy (1991, 1998). Schwab (1989, 1195-96), citing the distributive corollary, concludes that is "wrong" to rely on the Coase Theorem in favor of any particular political position or "ethical view on wealth distribution."

${ }^{10}$ See subsection 3.3 for a discussion of the importance of the difference between contractual and noncontractual settings.
} 
or will immediately arrive at a Pareto optimal point given transaction costs" (ibid., p. 1212). Hence, no moves from the status quo are possible without making someone worse off. We are always on the Pareto frontier; distributional issues are inevitable.

Furthermore, Calabresi finds Posner's ex-ante consent theory unconvincing. First, we typically do know something about winners and losers, and they are often not the same group: "Once we are no longer ignorant, any number of differences may cause us to believe that losses or gains to some matter more than losses or gains to others" (ibid., p. 1223; emphasis in original). Second, "no such [ex ante] social contract was ever made" (ibid., p. 1225) and, if there was, who is to say that Kaldor-Hicks would be the standard rather than, say, Rawls' maximin principle? ${ }^{11}$

The conclusion is that the effort to turn principles of efficiency - Pareto or Kaldor-Hicksinto neutral standards for evaluating legal rules did not succeed. It is impossible to ignore equity on these standards alone.

\subsection{Can Legal Rules Redistribute?}

To be clear then, legal rules are profoundly distributive. No one disputes this, as the embrace of the Kaldor-Hicks criterion and the Coase Theorem indicates. Yet some scholars argued that there was an important exception. This exception is when we attempt to redistribute between parties in a competitive market relationship. When parties are in market relationship, the cost of legal rules can be "passed on," frustrating the redistributive intent of the rule (Schwab, 1989, 1179) and (Polinsky, 1989, 123-24) 12 This led Polinsky $(1989,122)$ to conclude that "legal rules often cannot redistribute income in contractual disputes, whereas legal rules always can redistribute income in disputes between strangers."

For example, in an elegant analysis Hamada (1976) demonstrated that in a competitive market with potentially defective products, liability rules (no liability, negligence, or strict liability) make no difference to either the allocation of resources (i.e., efficiency) or to the distribution of income. Whatever the rule, the damages caused by a potential defect are either part of the implicit or explicit price of the good. In case of negligence, for instance, the buyer will be responsible for damages (as long as the seller has taken reasonable precautions). ${ }^{13}$ This may make for a nominally low explicit price for the good, but the buyer understands that the implicit price, which includes the potential cost of harm, is higher. Conversely, under a strict-liability rule the seller is liability for product accidents. But since

\footnotetext{
${ }^{11}$ Hypothetical social contract arguments generate different standards of judgment depending on how risk averse we believe people are behind the veil of ignorance. Risk neutrality yields Kaldor-Hicks; maximal risk aversion yields maximin.

${ }^{12}$ The existence of a competitive market relationship is indeed important. Schwab (1989, 1179): "In competitive markets, price equals cost and cost is the minimum possible cost; if the contract presumption would increase costs, the parties will write around it (assuming low transaction costs), and cost and price remain unchanged. But in markets where price can exceed cost, a favorable contract presumption may increase one's bargaining power. Even if the beneficiary waives the presumption, he may receive a greater share of the surplus for doing so."

${ }^{13}$ It is typically argued that either negligence or strict liability leads sellers to choose a reasonable or efficient level of precaution. The existence of competitive markets encourages the same under a rule of caveat emptor. Otherwise, a seller who takes an inefficiently low level of precaution will have higher costs than her competitors.
} 
the probability of accidents or their costs do not change with the liability rule, they will simply become part of the (higher) explicit price of the good. Thus, in competitive markets, liability rules make no difference to the distribution of income. ${ }^{14}$

Richard Craswell (1991) responded to competitive markets objection in a remarkably lucid analysis. ${ }^{15}$ Craswell says that whether legal rules can redistributive between parties in a competitive market depends on two conditions. First, consumers must be heterogeneous in their willingness to pay for the legal rule. Second, there must be a positive correlation between those willing to pay for the benefit of the legal rule and those willing to pay for the product or service itself. Under these conditions, legal rules can indeed be redistributive even in competitive market conditions. ${ }^{16}$

Consider whether a court should read an implied warranty into every contract for a sale of a product. Suppose also that all consumers would pay exactly the same amount for the addition of a warranty. Craswell shows in this homogenous case that consumers can only benefit from the addition of the warranty if their willingness to pay for it exceeds the cost of its addition to sellers. Since the benefit of the warranty exceeds its cost, the net benefit is positive. Conversely, if the benefit of the warranty does not exceed its cost, consumers suffer. Craswell concludes that "when consumers have identical preferences regarding a warranty or other legal rule, consumers will benefit from the rule if, and only if, the rule is efficient under a Kaldor-Hicks test" (ibid., p. 372) ${ }^{17}$ Since there is no conflict between efficiency and equity in this homogeneous case, the question of whether legal rules can redistribute is moot.

Compare this to the heterogeneous case. As a simplifying matter, suppose that the marginal consumers - those on the margin between buying or not buying the productvalue the warranty by an amount equal to the cost of the warranty to the sellers. Marginal consumers (as well as sellers) will therefore be indifferent to the addition of the warranty. On the other hand, if infra-marginal consumers (those willing to pay more for the product) also value the warranty highly, the addition of a warranty will make them strictly better off.

\footnotetext{
${ }^{14}$ In response to this "bargaining around" argument, it is sometimes objected that the costs of legal rules should be treated like the problem of tax incidence (see, e.g., Blumkin and Margalioth, 2005, 4-5). Who pays for a tax (or cost of a legal rule) depends on the relative elasticities of supply and demand. Depending on these elasticities either the buyer or the seller may primarily bear the burden of the tax (or cost of the legal rule). Thus, there is no general rule that sellers will be able to "pass on" the cost of a tax or legal rule.

Yet as Craswell (1991) demonstrated, this analogy is mistaken. A tax merely increases the cost of a product or service. In contrast, a legal rule increases the cost but also provides some benefit to the consumer (e.g., a warranty), and therefore changes her willingness to pay for it. Thus one cannot treat the effects of legal rules like taxes. Put slightly formally, the addition of a tax changes only product price and therefore quantity. These can be analyzed as moves along supply and demand curves. A legal rule, in contrast, often affects product quality. This induces shifts in supply and demand curves.

15 Kennedy (1981) explores a very similar economic analysis.

${ }^{16}$ Craswell demonstrates that Ackerman (1971) is a special case of his argument (see Craswell, 1991 380-83).

${ }^{17}$ Another interesting implication is that "the significance of sellers' ability to pass along their costs in such a market is exactly the opposite of what most people suppose" (ibid., p. 372). For example, if consumers value the warranty by less than its cost to sellers, sellers will be able to pass on less then 100 percent of that cost. But since consumers do not value the warranty very highly, this is a loss to consumers. Conversely, when consumers value the warranty more than it costs sellers, sellers will be able to pass on 100 percent of the costs.
} 
Conversely, if the infra-marginal consumers value the addition of the warranty less than the marginal consumers, consumers as a class are made worse off. It is therefore essential that those that value the product the most (the infra-marginal consumers) also value the legal rule the most.

The analysis gets more complicated when marginal consumers value the warranty more or less than its cost to sellers. However, there are conditions when, if the marginal consumer values the warranty less than its cost, consumers as a class will be better off and sellers worse off. In short, it is indeed possible for legal rules to redistribute in competitive markets. "The important point," as Craswell recognizes, "is that such a warranty might be regarded as good ... for consumers as a class even if it were inefficient under an overall Kaldor-Hicks standard" (ibid., p. 380, emphasis in original).

In sum, legal rules can indeed be redistributive. And not just in disputes between strangers, but within the competitive marketplace as well.

\subsection{Is the Income Tax Superior to Legal Rules in Redistributing Income?}

Fierce resistance thus confronted legal scholars who thought the economic analysis of legal rules should be concerned exclusively with efficiency rather than equity. First, the choice of standard for efficiency, Kaldor-Hicks, could not effectively allay concerns about distribution. Second, the distributive effects of legal rules could not be ignored - even in the case of competitive markets where it was believed that producers could simply pass on the cost of pro-consumer legal rules.

But if efficiency-only scholars had to concede the first two points, they began to concentrate on the third. That is, even if distribution was a normatively valid concern and even if legal rules has pervasive distributive consequences, legal rules are less effective in doing so than through income taxes. Note also that prevailing on this point would be an answer to the first question as well. If the tax-and-transfer system alone should address society's distributive concerns, then the evaluation of legal rules could focus on efficiency and ignore equity.

There are various supporting arguments for this claim, but the literature has boiled them down to three. The first can be called the "imprecision" or "haphazardness" argument (Polinsky, 1989, 124-27). Redistributive legal rules may favor tenants over landlords, employees over employers, and consumers over business owners. But each of these groups only imperfectly overlaps with rich and poor, as defined by income. Some consumers, after all, are quite rich. Redistribution through legal rules therefore depends on "crude averages" (Cooter and Ulen, 2016, 8). Income taxation, on the other hand, can be precisely tailored to target the problem we wish to solve: income inequality.

A second counter argument can be labeled the "bargaining around" argument (Polinsky, 1989, 122-23). We have seen this argument before in the previous section (3.3). The important point here is that although legal rules can redistribute, they are not guaranteed to do so effectively and may, in certain instances, pass on a significant amount of the costs to consumers. Broad-based income taxation avoids these kinds of highly-specific price effects, and is therefore a more effective redistributive tool (Cooter and Ulen, 2016, 8). 


\subsection{The Double-Distortion Argument}

There is also a third counter argument, considered by most to be the strongest argument for why the income tax is more efficient than legal rules in redistributing income. This is the "double distortion" argument by Kaplow and Shavell (1994).18 Kaplow and Shavell are quite conscious of the challenge that information economics presents to the Second Fundamental Theorem of welfare economics. They write:

[the debate between using legal rules and taxes] would be moot if the income tax system - understood here to include possible transfer payments to the poorcould be used freely to achieve any desired distribution of income. But income taxes and transfer payments distort incentives to work, limiting the degree to which it is socially desirable to employ the income tax system to redistribute income. (P. 667.)

They nevertheless are also adamantly clear in claiming, as manifested in their article's title, that "redistribution through legal rules offers no advantage over redistribution through the income tax system and typically is less efficient" (ibid.).

This conclusion follows from the "double distortion" caused by legal rules. Taxation causes a single distortion to labor-supply incentives, alternatively called the labor-leisure decision 19 Taxation reduces the rewards from work, and so individuals reduce their supply of labor to the market and/or allocate less time to paid activities and more time to leisure, causing a loss in wealth and output. In contrast, a redistributive legal rule not only distorts labor supply, but it "also creates inefficiencies in the activities regulated by the legal rules." Since it is better to have a single, rather than a double, distortion, switching to an efficient, non-redistributive legal rule will create a Pareto improvement. Through a modification of the tax schedule, the additional output can in fact be used to make the poor better off than they would be under the redistributive legal rule.

Let's summarize their example in order to make this claim more concrete. Suppose we have a tax regime where high-income individuals are taxed at a rate of 30 percent. Also suppose that we want to increase redistribution by using a legal rule that benefits the poor at the expense of the rich. In their main example, such a legal rule is a damages rule in tort that depends on the relative wealth of the injurer and victim: the damages an injurer pays increases with her income (relative to, say, average income). Assume this legal rule transfers an additional 1 percent of income from high earners to low earners. High-income individuals therefore pay 30 percent of each additional dollar to the tax system and 1 percent to the legal system.

Compare this regime to another regime with an efficient, non-redistributive legal rule. Their choice is strict liability, where an injurer, rich or poor, must pay for all harm caused 20

\footnotetext{
${ }^{18}$ An early version of the argument is found in Shavell (1981). The double-distortion argument has been defended in Kaplow and Shavell (2000b) and elaborated in Kaplow (1996). Kaplow and Shavell frequently cite in support of their argument Hylland and Zeckhauser (1979).

${ }^{19}$ Of course, there may be other distortions and costs as well, such as administrative burdens. But since a legal system obviously has administrative costs as well, these are typically ignored in the analysis of the economics of taxation.

${ }^{20}$ This rule is efficient because it internalizes an externality: the social costs caused by harm-inducing activities are now made private when individuals must pay for those harms.
} 
Suppose also that in this second regime we raise the tax rate for high earners to 31 percent.

Which regime should we choose? First, in terms of labor-supply incentives the regimes are identical. Thirty-one percent of a high-earner's income goes to the tax authorities in the second case, and is split between the tax and legal systems in the first case. But what a high earner gets to keep at the end of the day is the same. So the choice of regimes makes no difference for labor supply.

However, activities regulated by the legal rule will be different. With the income dependent damages rule, the rich spend too many resources on precaution and the poor too little, which causes more accidents. Resources are therefore saved with the efficient legal rule and these savings can be used to improve everyone's welfare (making it a Pareto improvement). ${ }^{21}$ As Kaplow and Shavell explain, "[B]ecause redistribution is accomplished in the presence of an efficient legal rule, resources would, by definition, be saved. With this savings, all individuals could be made better off (for example, by reducing taxes and increasing payments to the poor)" (idid., 668).

To conclude this section, legal rules may very well be redistributive. They can, in fact, improve the welfare and income of the poor. But there are powerful arguments that everyoneincluding the poor - could be made better off by redistributing exclusively through the tax system. This, in turn, becomes an argument for why the economic analysis of legal rules should be concerned solely with efficiency.

\section{Critiques of the Double-Distortion Argument}

Several critiques have been made of the double-distortion argument. None seem to have been successful in fully dismantling the claim. This section will try to understand why.

\subsection{Behavioral Economics}

Jolls (1998) applies behavioral economics to the issue of redistributive legal rules. She makes two arguments for why legal rules might distort work incentives less than taxes. First, people treat certain events (like taxes, which alongside death is the only thing certain in life) differently than uncertain events (like accidents). "People will tend to underestimate the probability that they will be hit with liability under a redistributive legal rule; therefore, their perceived cost of the rule will be lower" (ibid., p. 1662). For example, suppose a high-income person faces a tax bill of $\$ 10,000$. Suppose she also faces a .02 probability of causing an accident that incurs a tort liability of $\$ 500,000$. In expected terms, these two costs are the same $(.02 \times \$ 500,000=\$ 10,000)$. Because the accident is uncertain however, her perceived tort liability is lower than her tax liability. Accordingly, the tort damages will distort her work incentives less than the taxes. This may make the damages rule in tort a better tool for redistribution than taxes.

\footnotetext{
${ }^{21}$ Kaplow and Shavell approach the argument a slightly different way in their formal presentation. In place of the inefficient, redistributive legal rule, they propose a distribution-neutral adjustment to the tax schedule with the efficient rule. Because of the inefficiency in the legal rule, achieving a distributionallyneutral change requires higher taxes on the rich and lower transfers to the poor to account for the inefficient levels of accidents and precautionary costs. This generates a budget surplus, which can be rebated in the form of lower taxes and higher transfers and generates the Pareto improvement.
} 
The second reason Jolls gives for why legal rules will distort labor incentives less than taxes is that the costs of the two methods will be attributed to two different "mental accounts." "The idea behind 'mental accounting' is that people do not always view a dollar spent in the same way; it may matter very much from which 'account' the dollar is coming" (ibid., p. 1669) ${ }^{22}$ For instance, people probably see the cost of taxes as a direct charge against their income. In contrast, the cost of redistributive legal rules may be viewed as expenditures out of income. This is because an income-dependent damages rule is caused not just by a person's higher income (as it would be with taxes), but is also a product of the accident as well. Tax liability has a sole cause (income) while higher damages have a dual cause (income and accident). Jolls also argues that expenditures out of income will distort work incentive less than direct charges out of income. If such is the case, there may be an efficiency advantage to using legal rules rather than taxes to redistribute income.

However, Jolls attaches some significant caveats to her claims. She applies her analysis to individuals, rather than firms, which may in important cases overestimate the risk of certain harms (ibid., p. 1663). She focuses only on tort law, where "uncertainty" is paradigmatic; her analysis may not apply to other areas of law, such as contract (ibid., p. 1657-58). She acknowledges that the effects of insurance have unclear consequences for her claims (ibid., p. 1666). Her argument that people will attribute taxes and tort damages to different accounts is much more speculative than her claim about the underestimation of negative events ${ }^{23}$ Finally, Jolls also asks whether it is fair to use persons' cognitive biases to "disguise" taxation: "is it proper for government to make of this error in citizens' perception?" (ibid., pp. 1675-76, 1677). All of these considerations cast doubt on the extent to which behavioral economics favors legal rules over taxes to redistribute income.

\subsection{Heterogeneity}

Sanchirico (2000b) presents perhaps the most sophisticated critique to-date of the doubledistortion argument. Sanchirico contends that "even in the presence of an optimally redistributive tax, any concern for 'equity' dictates that legal rules should deviate from efficient standards in a manner that redistributes toward the less well-off" (ibid., p. 797). According

\footnotetext{
${ }^{22}$ Jolls $[1998,1669-70)$ gives the following illustration of mental accounting. Suppose you are going to watch a movie where the ticket price is $\$ 10$ and that you also lose $\$ 10$ along the way. Would you still pay $\$ 10$ to see the movie? Compare this with a slightly different scenario. Suppose you purchase your movie ticket ahead of time and later, just before entering the theater, you realize you have lost your ticket. Would you purchase another $\$ 10$ ticket? Under standard economic theory, these situations are identical. It is either worth purchasing the ticket or it is not, regardless of whether you lost $\$ 10$ cash or a $\$ 10$ movie ticket (or anything else worth $\$ 10$ ). However, actual responses to the two scenarios differ dramatically. "Eighty-eight percent of respondents in Case 1 would still pay $\$ 10$ for a ticket, but only forty-six percent of respondents in Case 2 would buy a new ticket" (ibid., p. 1669). The idea of mental accounting explains these different responses. In the first case, the lost money and the movie ticket are charged to "separate accounts." In the second case, both costs are charged to the same, "entertainment" account, which is perhaps more than what the individual wants to spend on that category.

23 "Much more would be necessary, of course, before reaching any sort of final conclusion about the effects of redistributive legal rules and taxes from a mental accounting perspective. The empirical evidence discussed above (and the other empirical evidence of which I am aware on the topic of mental accounting) involves contexts that are quite different from the one addressed in this Essay, and it may be that mental accounting is a highly context-specific phenomenon" (ibid., p. 1672).
} 
to Sanchirico, the missing element in Kaplow and Shavell (1994) is sufficient heterogeneity in individuals' characteristics ${ }^{24}$ For example, while Kaplow and Shavell assume in their formal model that persons are different in their ability to earn income, they also assume that people are identical (i.e., homogeneous) in, for example, their ability in taking precautions against accidents. Because of this identity, the income-dependent damages rule affects everyone similarly, leading only to a loss of efficiency. However, as Sanchirico argues, if individuals also differed in their precaution-taking abilities, an income-dependent damages rule will actually increase welfare.

Kaplow and Shavell (2000b) quickly responded to the heterogeneity critique. Kaplow and Shavell answered, “we believe Sanchirico's claim that our basic argument is subject to certain qualifications is correct but does not go to the heart of whether legal rules should be systematically adjusted to favor the poor and disfavor the rich in order to further distributive objectives" (ibid., p. 828). Suppose that rich yacht owners are prone to accidents ("klutzy") and that their victims are poor fishing boat owners. Should damages be raised to redistribute from the rich yacht owners to poor fisherman? Kaplow and Shavell say, "No." In fact, the legal rule should be adjusted to favor rich yacht owners and disfavor poor fisherman because a pro-defendant adjustment helps klutzier yacht owners, who are less well-off than their rich, non-klutzy peers. What about the poor? Kaplow and Shavell contend that an adjustment to the income tax could compensate fishing boat owners for lower damage payments. Thus, redistribution between rich and poor is kept the same while helping helping klutzes within the group of rich yacht owners. The bottomline: Sanchirico is technically correct, but "optimal adjustments to legal rules have no general, a priori relationship to the notion that legal rules should favor the poor in order to further redistributive objectives" (ibid., p. 832). According to Kaplow and Shavell, this is not redistribution in the conventional sense.

Sanchirico (2000a) mounted a rejoinder. He observed that neither were Kaplow and Shavell targeting income per se, but rather, like Sanchirico, were attempting to reduce inequality in overall well-being. In terms of Kaplow and Shavell's example (critiquing Sanchirico), "if the rich yacht owners are better-off overall [than poor fisherman], then Kaplow and Shavell have it backwards. ... [T] he equity adjustment to the tort system should favor the poor fishing-boat owners, and not the rich yacht owners" (ibid., p. 103536). Nevertheless, Sanchirico's (2000a; 2000b) own models show that whether legal rules should favor the rich or the poor depends on the covariance between income-earning ability and care-taking ability. It therefore remains unclear whether legal rules should favor or disfavor the rich 25

\subsection{Moral and Philosophical Objections}

As economists, Kaplow and Shavell are of course committed to efficiency and the other normative tools of welfare economics - all of which fall within the gambit of utilitarianism. One strategy of critique therefore has been to challenge the moral underpinnings of the double-distortion argument. One critique targets income (or wealth) and its ability (or inability) to serve as a "stand in" - a substitute or functional equivalent - for other values,

\footnotetext{
24 Avraham, Fortus and Logue (2003) also make the heterogeneity critique.

25 Gamage (2014, 14) draws a similar conclusion.
} 
norms, or goods. Another objection attacks more broadly the the moral adequacy of concepts such as utility, welfare maximization, and so forth.

One line of criticism takes Kaplow and Shavell to task for focusing on income redistribution. Such a focus will ignore characteristics other than income that may be desirable bases for redistribution. ${ }^{26}$ When other bases of redistribution exist, legal rules may be better equipped than the tax-and-transfer system to address them. Blumkin and Margalioth (2005) use the example of race discrimination. Suppose that because of discrimination (rather than ability) members of a racially-disfavored group earn less income than the racially-favored group. In principle, the income tax could be used to grant a refundable tax credit to members of the racially-disfavored group, and calculated to full eliminate race-based earnings differences. Yet, "[t]ransfers based on ethnic origin are not common in practice because of the desire to eliminate the ability of discriminators to purchase their right to discriminatewhich seems intrinsically immoral-and for symbolic reasons" (ibid., p. 16). Income is inadequate to address all forms of inequity.

Kaplow and Shavell have two responses to such criticisms. First, as we have already seen (e.g., Kaplow and Shavell, 2000b, 827-32), redistributing goods or values other than income falls outside the concern of their double-distortion argument. For Kaplow and Shavell, using legal rules "to redistribute" means "to redistribute income. ${ }^{27}$ Furthermore, they contend, a legal-rule adjustment made on some non-income basis is "qualitatively different from the adjustments that we suspect most legal academics have in mind when they talk about adjusting legal rules to favor the poor" (ibid., p. 829-30) ${ }^{28}$ Second, rules that address other forms of inequality - as anti-discrimination legislation - may actually be efficient and therefore pose no efficiency-equity tradeoff. ${ }^{29}$

Another line of criticism challenges the entire apparatus of Kaplow and Shavell's normative framework. Whether maximizing wealth or income, welfare or utility, their fundamentally utilitarian approach is said to ignore other fundamental norms and values - justice, rights, or fairness, for example ${ }^{30}$ In an extensive series of books and articles, Kaplow and

\footnotetext{
${ }^{26}$ See, for example, Blumkin and Margalioth $(2005,3)$; "people may have preferences for the means of redistribution which may have intrinsic value for them"; Lewinsohn-Zamir (2006, 331): "in lieu of the simplistic economic premise of source-independence, I submit that the benefit people derive from resources depends on complex factors, including the acts that generate the resources and the source from which they are received. ... The same quantity of goods may be more or less valuable depending on the mode of its production"; and Liscow (2014, 2502): one "reason for considering equity in legal rules is the goal of maximizing social welfare in ways the tax-and-transfer system is unable or poorly equipped to do - in particular, when characteristics other than income are desirable bases of redistribution."

${ }^{27}$ Liscow (2014, 2502) recognizes this: "[Kaplow and Shavell] are not "wrong' in not considering non-income factors; they are just asking a different question. The Kaplow-Shavell argument is a non sequitur in the context of redistribution for non-income reasons."

${ }^{28}$ Lewinsohn-Zamir (2006) makes a more subtle point about the difference between income and other "goods." Using the example of the warranty of habitability, she argues that income is no substitute for a "rat-infested, leaking and broken-down apartment." Such a dwelling "cannot grant the basic security, comfort and means that are essential for advancing self-respect and autonomous action, acquiring knowledge, pursuing long-term goals, or developing deep and meaningful social relationships with other people" (ibid., pp. 350-51).

${ }^{29}$ For a discussion of the efficiency of disparate impact rules, see, e.g., Ayres (2007).

${ }^{30}$ Taking a slightly different line of attack, Lewinsohn-Zamir (2006) accepts a consequential framework, like Kaplow and Shavell, but endorses instead an "objective" measure of well-being. Utility maximization,
} 
Shavell (1999; 2000a, 2001b, 2001a, 2003; 2009) have responded to such criticisms. Their position is that when evaluating legal policies, exclusive weight should be put on their effects on individuals well-being, with no independent ${ }^{31}$ weight accorded to notions of justice or fairness. However, discussing such fundamental issues threatens to take us away from our present topic. What can be said is that the debate between consequentialist and deontological approaches to ethics is unlikely to end soon. 32

\subsection{Political Action Costs}

A common, colloquial reaction to the double-distortion thesis is that it fails to recognize the political difficulties of enacting a robust, redistributive tax regime, let a lone an optimal or ideal one. Fennell and McAdams (2016) explore this intuition on the scholarly level.

Fennell and McAdams claim that the double-distortion argument's prescriptive advice rests on a "distributive-invariance" hypothesis ${ }^{33}$ This hypothesis states that the overall level of redistribution in society is fixed - unique - such that if a court, for example, were to adopt a redistributive legal rule, the legislature (reflecting the current political equilibrium) would offset the distributive change through a tax adjustment ${ }^{34}$ Endorsing the double-distortion argument's policy prescription "requires accepting the strong assumption that the distributive pattern in a society will be invariant to the political form of redistribution" (ibid., p. 1069-70). "If the amount of redistribution is fixed, then it is obvious that one should want to accomplish that redistribution in the most efficient way" (ibid., p. 1070). Conversely, if redistribution is not fixed and significant political costs prevent the introduction of a superior tax-and-transfer scheme, implementing redistribution through legal rules can increase welfare.

Fennell and McAdams convincingly undermine the the distributive-invariance hypothesis. For example, it is difficult to precisely and completely offset distributive legal rules, primarily for a reason often given against legal redistribution: it is haphazard. Also, legislative inertia - generated by institutional factors, such as veto points or federalism - prevents legislatures from responding to legal redistributions. Other reasons against distributive invariance are framing, salience, and other cognitive biases. For instance, prospect theory suggests that, since people weigh losses more heavily than gains, individuals will resist taxes, which highlight the "taking away" of something already possessed more than certain kinds

she says, assumes that people's well-being consists solely of satisfying their actual preferences, whatever those may be." The problem with this is that "[f]ulfillment of people's actual preferences might result in a reduction in their welfare, if their desires are based on misinformation, mistakes, or lack of self-respect and self-esteem" (ibid., p. 330). However, Kaplow and Shavell (2001b, 984, 1330-34) already appear to endorse an "objective" or at least "ideal" measure of welfare or well-being.

31 Kaplow and Shavell $2001 b, 968)$ distinguish this broader standard of evaluating legal rules from efficiency or wealth maximization. Furthermore, their idea of well-being is broad enough to encompass several notions of fairness. Moreover, they still adhere to their double-distortion argument which says that, in the case of income redistribution, legal rules should be chosen on the basis of efficiency or wealth maximization.

${ }^{32}$ For some of the responses to Kaplow and Shavell's approach to fairness versus welfare, see, e.g., Dorff (2001); Craswell (2003); Kornhauser (2003); Waldron (2003); Markovits (2004).

33 Markovits (2004) also recognizes and criticizes the distributive-invariance hypothesis.

${ }^{34}$ Fennell and McAdams explicitly acknowledge that they do not attribute to Kaplow and Shavell "one single, clearly stated proposition but rather a mostly unacknowledged premise revealed in scattered remarks" (ibid., p. 1072). 
of redistributive legal rules. Finally, people may assess the "fairness" of taxes and legal rules differently.

However, while Fennell and McAdams's critique of the distributive-invariance hypothesis is convincing, it is not clear how much the double-distortion argument actually depends on it. The real issue seems to be whether the political action costs of redistributing through legal rules is greater or lesser than taxation. This is implied from their discussion of distributive variance, which they claim invalidates the double-distortion argument. Suppose two different distributions of income are possible, one associated with a redistributive legal rule (Outcome $R$ ) and the other with the "closest politically achievable all-tax alternative" (Outcome T)(ibid., p. 1071). Using a social welfare function to measure distributive gains, then on "some imaginable social welfare function ... the distributive gains from Outcome $R$ relative to Outcome $T$ would outweigh the efficiency advantages of Outcome $T$ relative to Outcome R." But according to the double-distortion argument, there always exists a tax-alternative, call it Outcome $T^{\prime}$, that achieves higher social welfare than one using redistributive legal rules under any social welfare function: $T^{\prime}>R$ Thus, Fennell and McAdams's result $\left(T^{\prime}>R>T\right)$ can only be true if something-political action or some other costs - prevents Outcome $T$ from being as large as Outcome $T^{\prime}$ and these costs are greater than for achieving Outcome $R$. Thus, something more than distributive variance is needed to undermine the double-distortion argument.

Fennell and McAdams give several examples of why legal rules might have lower political action costs than taxation. But the reasons given seem just as likely to apply in reverseas many of their own examples indicate ${ }^{36}$ Furthermore, the same characteristics (framing, salience, cognitive biases, or fairness) given for the superiority of legal rules also tend to weaken their redistributive potency. Finally, there are few, if any, institutional differences between taxes and redistributive legal rules. Fennell and McAdams frequently invoke the scenario of a legislature responding to a court-adopted rule. But courts (relative to legislatures) have no exclusive domain over redistributive legal rules and it is not clear why courts would be more receptive to redistributive demands than legislatures. Thus, there are no strong reasons why the political action costs of legal rules should be systematically lower than taxation.

Also, the argument against distributive invariance does nothing to challenge the basic logic of the double-distortion thesis itself. As Fennell and McAdams frequently acknowledge, they distinguish Kaplow and Shavell's formal claim from a prescriptive claim. Their formal claim is the subject of this article: any level of redistribution can be achieved more efficiently through taxes than through legal rules. The prescriptive claim is the policy advice that follows from this: "ignore distributive considerations except when setting tax-and-transfer

\footnotetext{
${ }^{35}$ This is because under Kaplow and Shavell's analysis the tax reform is always a Pareto improvement, which implies that welfare will increase for any social welfare function. The choice of welfare function will only determine how the surplus for the tax reform will be distributed. If the social welfare function is maximally sensitive to inequality (e.g., Rawlsian) it will all go to the poor. If it is less sensitive to inequality some will also go to the rich.

${ }^{36}$ The "salience" of different forms and methods of taxation can vary greatly (e.g., "paycheck withholding or bundling with mortgage payments" (ibid., p. 1096)). Various forms of tax-and-transfer systems can be perceived as more or less "fair" (e.g., cash versus in-kind transfers restricted for certain, "legitimate" purposes (ibid., p. 1101-02)). Some forms of tax redistribution may be more politically sustainable than others (e.g., universal versus means-tested programs (ibid., p. 1088-89)).
} 
policy" (ibid., p. 1058). Yet, as Fennell and McAdams state, they "do not take issue with" Kaplow and Shavell's formal claim (ibid., p. 1057). Thus, whatever the political action costs of taxes or legal rules, this still leaves Kaplow and Shavell in a position to say that income taxation is a more efficient tool for redistribution than legal rules.

\subsection{Tax Distortions}

Another criticism of the double-distortion argument explores its implications within the domain of tax policy itself. When raising tax revenue, and even when implementing a labor income tax, policymakers have a variety of options to choose from: consumption taxes (which themselves can include valud-added taxes, sales taxes, or excise taxes), wealth taxes, or income taxes (which could be levied on labor income, capital income, or both). One version of the double-distortion argument says that only labor income taxes should be used 47 For example, suppose we want to tax yachts, which are purchased only by rich people, as a way to reduce inequality. The yacht tax distorts the labor-leisure (or labor supply) decision of the rich because it reduces the purchasing power of income, making work less attractive and leisure more so. But it also distorts the consumption decisions of the rich, causing them to purchase fewer yachts and more of other goods - this creates a second, or double, distortion. Accordingly, just like the previous double-distortion argument, the luxury tax can be replaced with a new, distribution-neutral income tax, and everyone made better off.

Not surprisingly, legal scholars have contested this application of the double-distortion argument as well. One line follows closely Sanchirico's heterogeneity critique ${ }^{38}$ Gamage (2014, 2015) explores another dimension: differences between various kinds of tax inefficiencies (or "distortions"). When analyzing income taxes, most economists focus on a single distortion: the trade-off between labor and leisure. But as Gamage points out, the labor-leisure distortion is hardly the only distortion caused by income taxation. In fact, more important is what Gamage calls "tax gaming" - tax avoidance or tax evasion. Tax gaming is inefficient because it wastes resources on avoiding or evading taxes that could be allocated to more productive uses. Indeed, especially for "high-income taxpayers, for whom distributional considerations are particularly relevant" tax gaming is of primary, and the labor-leisure distortion only of secondary, importance (Gamage, 2014, 5).

Tax gaming is important for the choice of tax instruments. Tax gaming distortions are "quite idiosyncratic and contingent" (ibid., p. 4). Indeed, Gamage argues that "taxpayers' incentives to engage in tax gaming ... are a direct function of only the tax rates of the labor income tax. ... [E]xcise tax rates should have only secondary effects on incentives to engage in [tax gaming]" (ibid., pp. 8-9). Therefore, it may indeed be optimal to impose the yacht tax as in the previous example. The luxury tax may distort labor-supply and consumption decisions, but it can also induce savings by lowering the income tax and the tax gaming associated with it. This is underscored by Gamage's focus on the "marginal cost of public funds." Since the economic costs of a tax instrument increases exponentionally in the tax

\footnotetext{
${ }^{37}$ Specifically, differential commodity taxation is inefficient in the presence of an optimal income tax, and uniform commodity taxation is useless. This result was first demonstrated in a famous paper by Atkinson and Stiglitz (1976). On similar assumptions, Kaplow (2006) demonstrated that this result holds under any income tax schedule, not just the optimal one.

${ }^{38}$ See, e.g., Saez (2002), Sanchirico (2010), Sanchirico (2011).
} 
rate, using many tax instruments at relatively moderate rates will be better than one, high rate on income (ibid., pp. 10-11, 20). This is called the "tax-smoothing" principle (Gamage, $2015,358)$.

One response to Gamage is to simply reform the income tax: remove the loopholes, differential rates, and other "idiosyncratic and contingent" factors that make tax gaming possible. This would improve efficiency and reduce the need to use multiple tax instruments, which Gamage acknowledges can also increase administrative and enforcement costs. Gamage (2014, 366) replies that "tax lawyers, accountants, and financiers ... can be expected to devise numerous tax gaming responses for exploiting any conceivable real world form of taxation." But surely the extent of gaming can be made to vary and perhaps reduced substantially, if not entirely. If not, we could ask whether, if tax gaming is such an inevitability, why any tax instrument is inherently less susceptible to it than another.

It is also not clear how far Gamage's analysis extends beyond the tax scenario. There is a discussion extending his argument to the use of non-tax legal rules (ibid, pp. 72-84), but certainly more research needs to be done in this area. Furthermore, since the kinds of taxes Gamage discusses are not also meant to regulate other behaviors, legal rules will always have additional distortions going beyond those of any tax. This may give little comfort to those who would seek to use legal rules, other than various forms of tax instruments, as tools for redistribution.

\section{New Directions in the Debate}

None of the criticisms of the double-distortion argument seem to have been able to dismantle it. Where does that leave us? For some time, the debate has subsided, leaving Weisbach (2003, 439) to declare: "The overwhelming majority of law and economics scholarship looks solely to efficiency to evaluate legal rules." However, the return of high-levels of economic inequality, both in fact and in public consciousness, suggests an opportunity to revisit the debate.

\subsection{The Return of Economic Inequality}

Throughout the 1980s and 1990s the issue of income inequality tended to fade as a matter of public policy concern. To the extent that economists discussed rising inequality, they spoke of "skill-biased technical change" (see Cahuc and Zylberberg, 2004, 587-95). This is the idea that income inequalities were being driven by technology, which was expanding jobs in high-skill sectors and contracting them in low-skill ones. The obvious solution to this problem was simply education.

The publication of Piketty and Saez (2003) signaled a shift in the scholarly consensus. Using tax record data, Piketty and Saez were able to get a much clearer look into the top of the income distribution - as precise as the top one percent of income earners (whence the slogan). Their data series, covering most of the twentieth century, suggested different explanations for the rise of income inequality at the end of the century. "We argue that both the downturn and the upturn of top wage shares seem too sudden to be accounted for by technical change alone" (ibid., p. 3). Instead, they suggest changes in labor market institutions, 
fiscal policy, or more generally social norms about pay inequality. Their data also indicate that the growth of income inequality is too concentrated at the top of the distribution to be explained by skill-biased technical change: "Stories based on the supply and demand for skills are not enough to explain the extreme top tail of the earnings distribution" (Alvaredo et al., 2013, 3). Finally, the publication of Piketty's (2014) Capital in the Twenty-First Century further cemented the changes taking place in public (and public-policy) discourse about the rise of income inequality.

Unsurprisingly, the change in public discourse surrounding income inequality has began to influence legal scholarship (e.g., Hsu, 2014, Kleinbard, 2017; Kwak, 2015) and, inevitably, has revived the debate around the double-distortion argument (e.g., Dimick, 2016, Fennell and McAdams, 2016; Liscow, 2014).

\subsection{Areas for Further Research}

In this subsection, I will layout my own views on the double-distortion argument and why I believe it comes up short. It also lays out a research agenda for my own future work, and one that I hope others will pursue as well.

The double-distortion argument rests on the assumption that redistributive legal rules will distort work incentives and the activities regulated by the legal rules. But why should this be so? In fact, it is easy to think of examples where, even if the legal rules distorts work incentives, the second - or double - distortion offsets rather than compounds the first.

Consider the following example of the minimum wage. Assume that there are just two households. One household is rich and owns a firm where labor is the only input; the other household is poor and supplies labor to the firm. It is often theorized that the cost of the minimum wage is at least partially offset by increases in labor productivity or reductions in labor costs (other than wages). For example, an increase in the minimum wage might increase worker effort or training or reduce costly turnover 39 Assume then that productivity is an increasing and concave function of the wage; and/or that other labor costs are a decreasing and convex function of the wage. We also assume perfect competition so that wages are set at the efficient, output-maximizing level. The "labor supply" of the rich household is captured by the number of workers employed. Since there are just two households, employers are taxed and workers receive transfers.

Now, say we increases taxes on the rich by one dollar, and transfers to the poor by a dollar. As is typical, this tax change produces only a "single" distortion: the rich will reduce output and employ fewer workers. This makes both rich and poor households worse off, but as long as the amount of distortion is smaller than a dollar, the poor are still better off and inequality is reduced.

Compare this to an increase in the minimum wage by one dollar. The effect of wage hike will be identical to the tax increase in the previous case, except for one crucial difference.

\footnotetext{
${ }^{39}$ There is an enormous literature debating the efficiency of the minimum wage beginning, first, with the classic argument about employer monopsony power (Robinson, 1969). But more current research emphasizes de facto monopsony power arising from labor market frictions (see, e.g., Acemoglu and Pischke, 1999 Acemoglu, 2001, Manning, 2003). In such models, minimum wages can reduce costly turnover (Dube, Lester and Reich, 2016) or increase productivity by increasing worker effort (Akerlof, 1982) or training (Acemoglu and Pischke, 1999).
} 
Because productivity is increasing in the wage (or other costs are falling or both), this second "distortion" partially offsets the first. 40 This means that the fall in output and reduction in employment will not be as large as in the tax case. As a result, the poor household is even better off than in the tax-only scenario and inequality still falls. Thus, the minimum wage is more efficient than taxes in redistributing income.

This is hardly an isolated example. Nor must this particular example be true in order for the general point to be valid. In fact, a variety of economic models in labor and employment law, antitrust, financial markets, housing markets, and consumer protection all demonstrate that legal rules can both increase efficiency and reduce inequality (Dimick, 2016). Now, because such rules increase efficiency in these models, a standard response is that they do not contradict the double-distortion argument. Since they are efficient, they are consistent with the basic premise that legal rules should be chosen on this basis alone. But if there are efficient redistributive legal rules, then a fortiori redistributive legal rules that are less inefficient than redistributive taxation are just as plausible. For any of the above-cited models, there almost certainly exist parameter values where the legal rule reduces efficiency, but by less than a distributionally-equivalent change in the tax schedule.

In fact, the double-distortion argument actually lowers the threshold required to justify these kinds of market interventions. Typically, the threshold is whether the legal change is efficient or not. In contrast, given the existence of costly redistributive taxation, the doubledistortion argument suggests that some inefficiency is perfectly tolerable - as long as it is less inefficient than the best tax alternative. The debate over the minimum wage is an example of this. Much empirical work disagrees about whether the minimum wage induces any loss in employment. But, given what we have just said, losses in employment are perfectly acceptable as long as they are smaller than what would be induced by a distributionallyequivalent tax change.

\subsection{Conclusion}

A long-standing debate asks whether legal rules or only the income tax should be used to redistribute income. This article has traced this debate from its inception in law-and-economics scholarship. Scholars found unconvincing the claims that efficiency standards, such as Pareto or Kaldor-Hicks efficiency, could legitimately ignore the distributive consequences of legal rules. Scholars also demonstrated that legal rules could in fact be redistributive in a variety of scenarios, including in contractual or market relationships where it was alleged that sellers could simply "pass on" the costs of legal rules to buyers.

However, proponents of the efficiency- and tax-only view of legal-rule analysis developed a powerful counterargument. This argument is that, even if legal rules could redistribute, the income tax is more efficient in doing so. Consequently, law-and-economics scholars could still ignore the distributive implications of legal rules. Perhaps the most convincing argument for this position is the "double-distortion" argument developed by Kaplow and Shavell (1994).

This article has also reviewed the critiques of the double-distortion argument, which seem to have had only limited impact on its reputation within the debate. However, along the

\footnotetext{
${ }^{40}$ Indeed, although productivity increases it is indeed a distortion in a non-trivial sense because it is not optimal-productivity is too high from an efficiency point view and does not fully offset the wage increase.
} 
lines I have set out, I believe there are still unexplored grounds for challenging the doubledistortion argument, and for giving the greater standing to the distributive analysis of legal rules in legal scholarship. 


\section{References}

Acemoglu, Daron. 2001. "Good Jobs versus Bad Jobs." Journal of Labor Economics, 19(1): 1-21.

Acemoglu, Daron, and Jörn-Steffen Pischke. 1999. "The Structure of Wages and Investment in General Training." Journal of Political Economy, 107(3): 539-572.

Ackerman, Bruce. 1971. "Regulating Slum Housing Markets on Behalf of the Poor: Of Housing Codes, Housing Subsidies and Income Redistribution Policy." Yale Law Journal, 80(6): 1093-1197.

Akerlof, George A. 1982. "Labor contracts as partial gift exchange." Quarterly Journal of Economics, 97(4): 543-569.

Alstott, Anne L. 1999. "Work vs. freedom: A liberal challenge to employment subsidies." The Yale Law Journal, 108(5): 967-1058.

Alvaredo, Facundo, Anthony B Atkinson, Thomas Piketty, and Emmanuel Saez. 2013. "The top 1 percent in international and historical perspective." Journal of Economic Perspectives, 27(3): 3-20.

Atkinson, Anthony Barnes, and Joseph E Stiglitz. 1976. "The Design of Tax Structure: Direct Versus Indirect Taxation." Journal of Public Economics, 6(1-2): 55-75.

Avraham, Ronen, David Fortus, and Kyle Logue. 2003. "Revisiting the Roles of Legal Rules and Tax Rules in Income Redistribution: A Response to Kaplow \& Shavell." Iowa Law Review, 89: 1125.

Ayres, Ian. 2007. "Market power and inequality: A competitive conduct standard for assessing when disparate impacts are unjustified." California Law Review, 95(3): 669-720.

Blumkin, Tomer, and Yoram Margalioth. 2005. "On the Limits of Redistributive Taxation: Establishing a Case for Equity-Informed Legal Rules." Virginia Tax Review, 25(1): 129.

Cahuc, Pierre, and André Zylberberg. 2004. Labor Economics. . 1 ed., MIT Press.

Calabresi, Guido. 1991. "The pointlessness of Pareto: Carrying Coase further." Yale Law Journal, 100: 1211-1237.

Coleman, Jules L. 1979. "Efficiency, utility, and wealth maximization." Hofstra Law Review, 8: 509-551.

Cooter, Robert, and Thomas Ulen. 2016. Law and Economics. . 6 ed., Boston:AddisonWesley.

Craswell, Richard. 1991. "Passing on the costs of legal rules: Efficiency and distribution in buyer-seller relationships." Stanford Law Review, 43(2): 361-398.

Craswell, Richard. 2003. "Kaplow and Shavell on the Substance of Fairness." Journal of Legal Studies, 32(1): 245-275.

Dimick, Matthew. 2016. "Should the Law Do Anything about Economic Inequality?" Cornell Journal of Law \& Public Policy, 26: 1.

Dorff, Michael B. 2001. "Why welfare depends on fairness: A reply to Kaplow and Shavell." Southern California Law Review, 75: 847.

Dube, Arindrajit, T William Lester, and Michael Reich. 2016. "Minimum wage 
shocks, employment flows, and labor market frictions." Journal of Labor Economics, 34(3): 663-704.

Fennell, Lee Anne, and Richard H McAdams. 2016. "The Distributive Deficit in Law and Economics." Minnesota Law Review, 100: 1051-1129.

Gamage, David. 2014. "How Should Governments Promote Distributive Justice?: A Framework for Analyzing the Optimal Choice of Tax Instruments." Tax Law Review, 68: 187.

Gamage, David. 2015. "The Case for Taxing (All of) Labor Income, Consumption, Capital Income, and Wealth." Tax Law Review, 68: 355-441.

Hale, Robert L. 1923. "Coercion and distribution in a supposedly non-coercive state." Political Science Quarterly, 38(3): 470-494.

Hale, Robert L. 1943. "Bargaining, duress, and economic liberty." Columbia Law Review, 43(5): 603-628.

Hamada, Koichi. 1976. "Liability Rules and Income Distribution in Product Liability." American Economic Review, 66(1): 228-234.

Hasen, David. 2006. "Liberalism and Ability Taxation." Texas Law Review, 85: 1057.

Hindriks, Jean, and Gareth D Myles. 2013. Intermediate Public Economics. MIT Press.

Hsu, Shi-Ling. 2014. "The Rise and Rise of the One Percent: Considering the Legal Causes of Wealth Inequality." Emory Law Journal Online, 64: 2043-72.

Hylland, Aanund, and Richard Zeckhauser. 1979. "Distributional Objectives Should Affect Taxes but Not Program Choice or Design." Scandinavian Journal of Economics, 81(2): 264-284.

Jolls, Christine. 1998. "Behavioral economics analysis of redistributive legal rules." Vanderbilt Law Review, 51: 1653.

Kaplow, Louis. 1996. "The optimal supply of public goods and the distortionary cost of taxation." National Tax Journal, 49(4): 513-533.

Kaplow, Louis. 2006. "On the undesirability of commodity taxation even when income taxation is not optimal." Journal of Public Economics, 90(6): 1235-1250.

Kaplow, Louis, and Steven Shavell. 1994. "Why the Legal System is Less Efficient than the Income Tax in Redistributing Income." Journal of Legal Studies, 23(2): 667-681.

Kaplow, Louis, and Steven Shavell. 1999. "The conflict between notions of fairness and the Pareto principle." American Law and Economics Review, 1(1): 63-77.

Kaplow, Louis, and Steven Shavell. 2000a. "Notions of fairness versus the Pareto principle: on the role of logical consistency." Yale Law Journal, 110(2): 237-249.

Kaplow, Louis, and Steven Shavell. 2000b. "Should Legal Rules Favor the Poor? Clarifying the Role of Legal Rules and the Income Tax in Redistributing Income." Journal of Legal Studies, 29(2): 821-835.

Kaplow, Louis, and Steven Shavell. 2001a. "Any non-welfarist method of policy assessment violates the Pareto principle." Journal of Political Economy, 109(2): 281-286.

Kaplow, Louis, and Steven Shavell. 2001b. "Fairness versus welfare." Harvard Law Review, 114: 961-1388.

Kaplow, Louis, and Steven Shavell. 2003. "Fairness versus welfare: notes on the Pareto 
principle, preferences, and distributive justice." Journal of Legal Studies, 32(1): 331-362.

Kaplow, Louis, and Steven Shavell. 2009. Fairness versus welfare. Harvard University Press.

Kelman, Mark. 1987. A guide to Critical Legal Studies. Harvard University Press.

Kennedy, Duncan. 1981. "Distributive and paternalist motives in contract and tort law, with special reference to compulsory terms and unequal bargaining power." Maryland Law Review, 41(4): 563-658.

Kennedy, Duncan. 1987. "The effect of the warranty of habitability on low income housing: "milking" and class violence." Forida State University Law Review, 15: 485-519.

Kennedy, Duncan. 1991. "The Stakes of Law, or Hale and Foucault!" Legal Studies Forum, 15: 327 .

Kennedy, Duncan. 1998. "Law and Economics from the perspective of Critical Legal Studies." In The New Palgrave Dictionary of Economics and the Law. Vol. 2, , ed. Peter Newman, 465-474. New York:Stockton Press.

Kleinbard, Edward D. 2017. "Capital Taxation in an Age of Inequality." Southern California Law Review, 90(3): 593-682.

Komesar, Neil K. 1973. "Return to Slumville: A Critique of the Ackerman Analysis of Housing Code Enforcement and the Poor." Yale Law Journal, 82(6): 1175-1193.

Komesar, Neil K. 1983. "Revolution in Landlord-Tenant Law: A Comparative Institutional View." Cornell Law Review, 69: 612-622.

Kornhauser, Lewis A. 2003. "Preference, well-being, and morality in social decisions." Journal of Legal Studies, 32(1): 303-329.

Kwak, James. 2015. "Reducing Inequality with a Retrospective Tax on Capital." Cornell Journal of Law \& Public Policy, 25: 191-244.

Lewinsohn-Zamir, Daphna. 2006. "In defense of redistribution through private law." Minnesota Law Review, 91: 326-397.

Liscow, Zachary. 2014. "Reducing Inequality on the Cheap: When Legal Rule Design Should Incorporate Equity as Well as Efficiency." Yale Law Journal, 123(7): 2478-2510.

Manning, Alan. 2003. "Monopsony in motion: Imperfect competition in labor markets."

Markovits, Richard S. 1976. "The distributive impact, allocative efficiency, and overall desirability of ideal housing codes: some theoretical clarifications." Harvard Law Review, 1815-1846.

Markovits, Richard S. 2004. "Why Kaplow and Shavell's Double-Distortion Argument Articles Are Wrong." George Mason Law Review, 13: 511-619.

McCaffery, Edward J. 2005. "A New Understanding of Tax." Michigan Law Review, 103(5): 807-938.

Piketty, Thomas. 2014. Capital in the 21st Century. Cambridge, MA:Harvard University Press.

Piketty, Thomas, and Emmanuel Saez. 2003. "Income Inequality in the United States, 1913-1998." The Quarterly Journal of Economics, 118(1): 1-41.

Polinsky, A Mitchell. 1989. An Introduction to Law and Economics. . 2 ed., Aspen Publishers. 
Posner, Richard A. 1979. "The ethical and political basis of the efficiency norm in common law adjudication." Hofstra Law Review, 8: 487-507.

Rabin, Edward H. 1983. "Revolution in residential landlord-tenant law: causes and consequences." Cornell Law Review, 69: 517-584.

Rawls, John. 1999. A Theory of Justice. Oxford University Press.

Robinson, Joan. 1969. The economics of imperfect competition. Springer.

Saez, Emmanuel. 2002. "The desirability of commodity taxation under non-linear income taxation and heterogeneous tastes." Journal of Public Economics, 83(2): 217-230.

Sanchirico, Chris William. 2000a. "Deconstructing the New Efficiency Rationale." Cornell Law Review, 86: 1003-1089.

Sanchirico, Chris William. 2000b. "Taxes versus Legal Rules as Instruments for Equity: A More Equitable View." Journal of Legal Studies, 29(2): 797-820.

Sanchirico, Chris William. 2010. "A Critical Look at the Economic Argument for Taxing Only Labor Income." Tax Law Review, 63: 867-956.

Sanchirico, Chris William. 2011. "Tax Eclecticism." Tax Law Review, 64: 149-227.

Schwab, Stewart. 1989. "Coase Defends Coase: Why Lawyers Listen and Economists Do Not." Michigan Law Review, 87(6): 1171-2459.

Shavell, Steven. 1981. "A Note on Efficiency vs. Distributional Equity in Legal Rulemaking: Should Distributional Equity Matter Given Optimal Income Taxation?" American Economic Review, 71(2): 414-418.

Stark, Kirk J. 2005. "Enslaving the Beachcomber: Some Thoughts on the Liberty Objections to Endowment Taxation." Canadian Journal of Law $\mathcal{E}$ Jurisprudence, 18(1): 47-68.

Waldron, Jeremy. 2003. "Locating distribution." Journal of Legal Studies, 32(1): 277-302.

Weisbach, David A. 2003. "Should Legal Rules Be Used to Redistribute Income?" University of Chicago Law Review, 70(1): 439-453.

Zelenak, Lawrence. 2006. "Taxing Endowment." Duke Law Journal, 55: 1145. 